

\title{
STATEGI PENGAWASAN, IDENTIFIKASI KAPAL DAN PERAN KELOMPOK MASYARAKAT NELAYAN DALAM PENGAWASAN KAPAL PENANGKAP IKAN PARI DI PERAIRAN CILACAP
}

\author{
*Yogi Putranto \\ * Stasiun Pengawasan Sumber Daya Kelautan dan Perikanan Cilacap, Direktorat Jenderal \\ Pengawasan Sumber Daya Kelautan dan Perikanan, Kementerian Kelautan dan Perikanan \\ *Corresponding author: yogiputranto30@gmail.com
}

Received 5 May 2019; Accepted 27 June 2019; Available online 28 June 2019

\begin{abstract}
Abstrak
Laju penangkapan ikan pari di Indonesia setiap tahun mengalami kenaikan yang signifikan. Hal tersebut menyebabkan terancamnya kelangsungan hidup dari spesies ikan pari serta terganggunya habitat dan ekosistem yang disebabkan oleh banyaknya penangkapan ikan pari di perairan Cilacap. Spesies pari manta bahkan di tetapkan oleh Kementerian Perikanan dan Kelautan sebagai spesies yang mendapatkan perlindungan penuh dikarenakan spesies tersebut sudah langka di Perairan Indonesia. Penelitian ini bertujuan mengetahui strategi pengawasan serta mengidentifikasi kapal perikanan yang melakukan penangkapan ikan pari di Perairan Cilacap. Penelitian ini dilakukan dengan cara pengambilan data kapal yang melaporkan kedatangan kepada Stasiun Pengawasan Sumberdaya Kelautan dan Perikanan Cilacap dari Bulan Januari sampai dengan bulan Desember 2018. Hasil penelitian pada periode penelitian tersebut menyebutkan bahwa kapal yang melaporkan kedatangan di Pos Pelayanan Terpadu Pelabuhan Perikanan Samudera Cilacap sebanyak 1.405 kapal. Dari 1.405 kapal yang melapor kedatangan, terdapat 168 kapal penangkap ikan pari. Jumlah penangkapan ikan pari terbanyak dilakukan KM. Mina Sempurna 99 dengan alat tangkap Purse Seine. Selain itu produktifitas ikan pari yang didaratkan di Pelabuhan Perikanan Samudera Cilacap sebanyak 1.261.918 kg. (1.261 ton), tertinggi di bulan Agustus sebanyak $467.939 \mathrm{~kg}$ (467 ton) dan terendah di bulan Januari sebanyak $45 \mathrm{~kg}$. Dengan data yang diperoleh tersebut, maka stategi pengawasan kapal ikan pari khususnya di bulan Agustus sampai dengan Desember diantaranya melalui pengetatan pemeriksaan kedatangan kapal perikanan serta digitalisasi penandaan melalui stiker barcode terhadap kapal penangkap ikan pari. Dengan adanya penelitian ini diharapkan mampu memberikan kontribusi positif terhadap upaya pelestarian dan konservasi ikan pari di Indonesia khususnya di Perairan Cilacap.
\end{abstract}

Kata Kunci : kapal penangkap ikan pari, perairan Cilacap. 


\begin{abstract}
The rate of catching stingrays in Indonesia every year has increased significantly. This causes the survival of stingray species and the disturbance of habitats and ecosystems that are threatened by the large number of stingrays caught in the waters of Cilacap. The manta ray species is even determined by the Ministry of Fisheries and Marine Affairs as a species that gets full protection because the species is already rare in Indonesian waters. This study aims to determine the supervision strategy and identify fishing vessels that capture stingrays in the waters of Cilacap. This research was carried out by collecting ship data that reported arrival to the Cilacap Marine and Fisheries Resources Monitoring Station from January to December 2018. The results of the study in the study period stated that the ships reported arrival at the Cilacap Ocean Fisheries Port Integrated Service Post of 1,405 ship. Of the 1,405 ships reporting arrival, there are 168 stingrays. The highest number of stingrays is carried out by KM. Mina Sempurna 99 with Purse Seine capture tool. In addition, the productivity of stingrays landed at the Cilacap Ocean Fisheries Port is 1,261,918 kg. (1,261 tons), the highest in August was $467,939 \mathrm{~kg}$ (467 tons) and the lowest in January was $45 \mathrm{~kg}$. With the data obtained, the strategy for monitoring stingrays, especially in August to December, is through tightening inspection of fishing vessel arrivals and digitizing markings through barcode stickers on stingrays. The existence of this research is expected to be able to contribute positively to the conservation and conservation efforts of stingrays in Indonesia especially in Cilacap
\end{abstract}

Keywords: Stingray fishing vessel, Cilacap waters.

\title{
1. PENDAHULUAN
}

Salah satu negara yang memanfaatkan tangkapan ikan Elasmobranchii khususnya ikan pari (family Dasyitidae) dalam jumlah yang banyak adalah Indonesia. Bahkan Indonesia dapat dikatakan sebagai salah satu yang terbesar. Namun upaya konservasi terhadap ikan pari tersebut tersebut belum cukup baik, terbilang masih sangat rendah. Bahkan di beberapa tempat di Indoensia terjadi perburuan besar- besaran terhadap ikan pari diantaranya di Perairan Lamakera dan Lamalera di Nusa Tenggara Timur. Penangkapan dalam jumlah yang relative masiv dengan menggunakan kapal perikanan juga terjadi di Perairan Selatan Jawa khususnya Perairan Cilacap. Beberapa kapal perikanan bahkan terindikasi melakukan penangkapan ikan jenis ikan pari sebagai hasil tangkapan utama. Oleh karena itu diperlukan penelitian untuk mengidentifikasi kapal pe stategi pengawasan terhadap kapal penangkapan ikan pari tersebut agar kelestarian sumber daya ikan pari tersebut dapat terjaga.

Berdasarkan data produksi yang diterbitkan oleh SEADFEC (2013) penangkapan ikan Elasmobranchii Indonesia pada tahun 2013 mencapai 101.991 ton. Fakta tersebut menjadi kebanggaan dan sekaligus kekhawatiran terhadap populasi Elasmobranchii di Indonesia. Tahun 1987, hasil tangkapan dari Elasmobranchii di Indonesia tercatat sebesar 36.884 ton, tahun 2000 hasil tangkapannya meningkat hampir dua kali lipat sebesar 68.366 ton (Dharmadi dan Fahmi, 2003).

Data IUCN (2015) menyebutkan bahwa status konservasi ikan pari di alam dari 156 spesies ikan pari, 10 spesies kategori endengered, 3 spesies kategori critically endangered, 21 
spesies termasuk near threatened, 27 spesies vulnerable, 33 spesies least concern dan yang paling banyak 62 spesies kategori data deficient. Status konservasi ikan pari yang semakin terancam ini diduga akibat perburuan yang berlebih serta perkembangan yang cukup sulit dan memakan waktu yang lama bagi ikan pari tersebut. Elasmobranchii saat ini sedang menghadapi masalah terhadap tingginya laju kepunahan akibat pengambilan ikan berlebih (over fishing) yang dipicu oleh tingginya permintaan pasar akan daging dan kulit pari serta sirip hiu. Faktor lain yang menyebabkan tingginya laju kematian Elasmobranchii adalah tingkat kematian alami tinggi pada berbagai tingkat umur dan penurunan kualitas perairan akibat pencemaran. Penangkapan yang dilakukan oleh nelayan cenderung tidak didasari oleh ketersediaan informasi dan data ilmiah mengenai status konservasi Elasmobranchii. Laju penangkapan Elasmobranchii di Indonesia tinggi, hal ini ditunjukkan oleh hasil tangkapan yang naik secara signifikan dari tahun ke tahun (Camhi et al., 1998).

Stasiun Pengawasan Sumberdaya Kelautan dan Perikanan Cilacap merupakan salah satu Unit Pelaksana Teknis Direktorat Jenderal Pengawasan Sumberdaya Kelautan dan Perikanan yang dibentuk berdasarkan Peraturan Menteri Kelautan dan Perikanan Nomor 33/PERMENKP/2016 Tentang Organisasi Dan Tata Kerja Unit Pelaksana Teknis Pengawasan Sumber Daya Kelautan Dan Perikanan. Salah satu tugas Penagwas Perikanan yang disebutkan dalam Peraturan Menteri Kelautan dan Perikanan Nomor :17/PERMEN-KP/2014 Tentang Pelaksanaan Tugas Pengawas Perikanan, adalah memeriksa kesesuaian ikan hasil tangkapan dengan alat penangkapan ikan. Selain pemeriksaan fisik terhadap hal tersebut, Stasiun PSDKP Cilacap juga menerima laporan kedatangan kapal dari nahkoda kapal perikanan.

Hingga saat ini belum ada penelitian tentang strategi pengawasan dan identifikasi kapal penangkap ikan pari di Perairan Cilacap. Hal ini menjadi penting dilakukan karena status konservasi ikan pari yang terbilang rentan dan juga tingginya konsumsi dan penggunaan dari bagian tubuh ikan pari menyebabkan terancamnya kelangsungan hidup dari spesies ikan pari tersebut dan juga terganggunya habitat dan ekosistem yang disebabkan oleh banyaknya perburuan liar ikan pari di perairan Indonesia khususnya di perairan selatan Jawa. Oleh karena itu diperlukan penelitian untuk mengidentifikasi kapal perikanan yang menangkap ikan pari serta strategi pengawasannya.

\section{MATERI DAN METODE}

\subsection{Lokasi Penelitian}

Pengambilan data dilakukan di Pos Pelayanan Terpadu Pelabuhan Perikanan Samudera Cilacap dengan data yang diambil merupakan data yang melapor kedatangan kapal selama periode Januari s/d Desember 2018.

\subsection{Metode Penelitian}

Metode yang digunakan dalam penelitian ini yaitu metode survey. Survey dilakukan terhadap Pengawas Perikanan Stasiun PSDKP Cilacap yang bertugas di Pos Pelayanan Terpadu Pelabuhan Perikanan Samudera Cilacap, sementara metode analisis deskriptif yaitu dengan mengolah data kapal yang melapor kedatangan untuk kemudian dinarasikan kedalam bentuk penjelasan. 


\section{HASIL DAN PEMBAHASAN}

\subsection{Data Kedatangan Kapal Perikanan}

Kapal perikanan yang melapor selama periode bulan Januari s/d Desember 2018 di Pos Pelayanan Terpadu Pelabuhan Perikanan Samudera Cilacap sebanyak 1.405 kapal (Gambar 1)



Gambar 1. Kapal Yang Melapor Kedatangan Selama Periode Januari sd Desember 2018

Data rekapitulasi kedatangan kapal perikanan Stasiun Pengawasan Sumberdaya Kelautan dan Perikanan menunjukan fluktuasi kedatangan kapal berkaitan erat dengan periode penangkapannya. Gambar 1 memperlihatkan bahwa bulan Agustus merupakan puncak kedatangan kapal perikanan (173 kapal), sementara yang terendah terjadi pada bulan Februari (41 kapal). Peningkatan kedatangan kapal mulai terjadi bulan Agustus hingga Desember, Hal tersebut sejalan dengan pola penangkapan ikan di wilayah Perairan Selatan Jawa yang mengenal dua jenis musim. Musim angin timuran dan musim angin baratan. ketika angin baratan, tiba musim penghujan, sehingga kerap disertai dengan cuaca buruk. Ombak tinggi, angin kencang, disertai hujan lebat kerap mengancam nelayan. Periode bulan Agustus sampai dengan Desember merupakan periode yang tepat dalam penangkapan ikan.

\subsection{Klasifikasi Alat Tangkap Ikan}

Berdasarkan klasifikasinya, alat tangkap yang mealporkan kedatangan terbagi menjadi 13 (tiga belas) kelompok alat penangkapan ikan (Tabel 1). 
Tabel 1. Klasifikasi Alat Tangkap

\begin{tabular}{|c|l|c|}
\hline NO & JENIS ALAT TANGKAP & JUMLAH \\
\hline 1 & GILLNET & 89 \\
\hline 2 & HAND LINES & 1 \\
\hline 3 & JARING INGSANG OSEANIK & 4 \\
\hline 4 & JARING INSANG HANYUT & 9 \\
\hline 5 & JARING INSANG OSEANIK & 137 \\
\hline 6 & LONG LINE & 9 \\
\hline 7 & PANCING CUMI & 2 \\
\hline 8 & PANCING ULUR & 12 \\
\hline 9 & PANCING ULUR (HAND LINE) & 6 \\
\hline 10 & PURSE SEINE PELAGIS BESAR & 1 \\
\hline 11 & RAWAI DASAR & 14 \\
\hline 12 & RAWAI HANYUT & \\
\hline 13 & SQUID JIGGING & \\
\hline
\end{tabular}

Tabel 1 memperlihatkan bahwa alat tangkap long line merupakan alat tangkap yang dominan yang ada di Perairan Cilacap (137 kapal). Tingginya penggunaan alat tangkap longline karena long line merupakan alat tangkap yang disesuikan dengan ikan sasaran. Ikan sasaran yang paling banyak di Perairan Selatan Jawa dan Samudera Hindia adalah ikan tuna yang melakukan migrasi dengan wilayah geografis dengan spektrum yang luas (Saputra, dkk, 2011)

\subsection{Produktifikatas Ikan Pari yang di Daratkan}

Ikan pari yang didaratkan sampai dengan bulan Desember sebanyak 1.261.918 kg. (1.261 ton), dengan pendaratan ikan pari terbanyak terjadi di bulan Agustus (467.939 kg) sementara dan terendah terjadi di bulan Januari (45 kg). (Gambar 2). Peningkatan jumlah ikan yang didaratkan ikan pari yang didaratkan disebabkan oleh periode musim pemijahan ikan pari serta pada bulan Agustus sampai dengan Desember, factor makanan ikan pari tersedia cukup banyak. Makanan adalah salah satu factor dasar yang mempengaruhi kehidupan ikan baik secara individual mapun populasinya (Schreck dan Moyle, 1990). Keterbatasan suplai makanan akan mengakibatkan kompetisi antar individu (bahkan antar spesies) yang dapat menyebabkan penurunan rekruimennnya. Makanan, factor ekologi dan kondisi fisiologis ikan dapat memberikan petunjuk produksi biomassa (Holden dan Raitt, 1975). Peregerakan dan modifikasi populasi ikan terutama disebabkan oleh pencarian makanan dan tempat memijah.

Peningkatan ikan pari yang didaratkan yang terjadi pada bulan Agustus sampai dengan Desember perlu mendapatkan stategi pengawasan yang tepat. Beberapa stategi pengawasan yang disarankan diantaranya penerbitan aturan atau regulasi yang tepat berkaitan pengeluaran ikan pari dari pelabuhan pangkalan pendaratan ikan atau regulasi tentang distribusi peredaran ikan pari di masyarakat. Sejauh ini Kementerian Kelautan dan Perikanan hanya baru memproteksi dan 
melindungi ikan pari melalui Keputusan Menteri Kelautan dan Perikanan Nomor 4/KEPMENKP/2014 tentang Penetapan Status Perlindungan Penuh Ikan Pari Manta

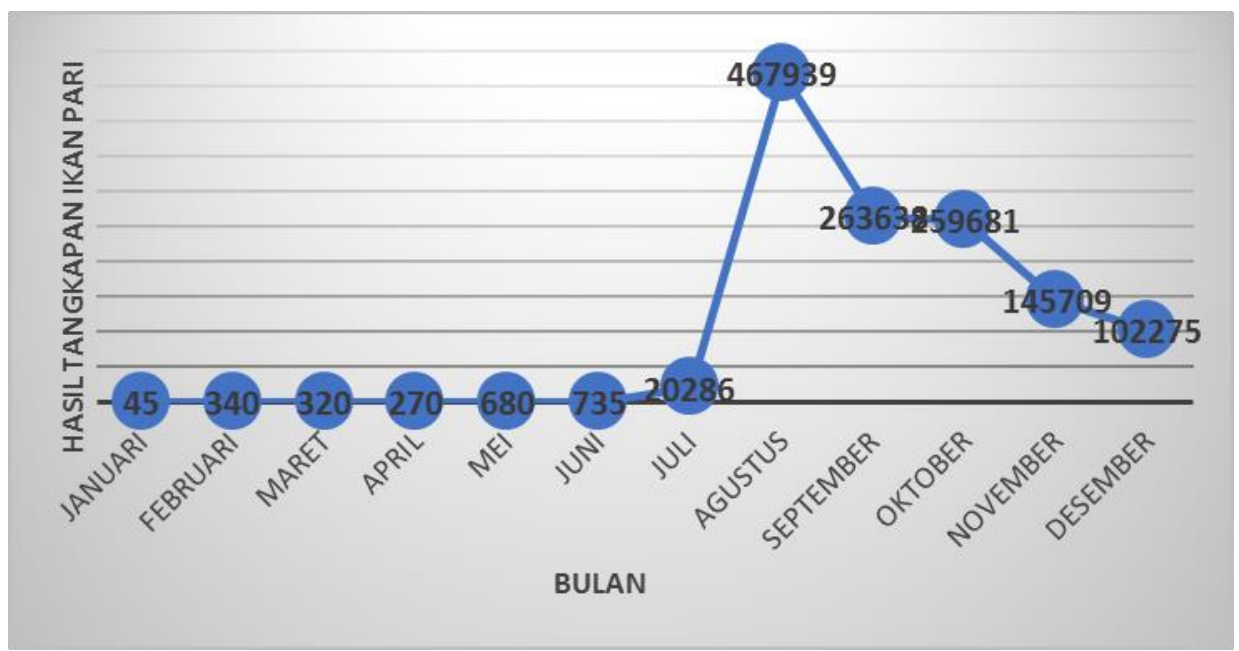

Gambar 2. Pendaratan Ikan Pari

\subsection{Identifikasi Kapal Penangkap Ikan Pari}

Hasil rekapitulasi kapal penangkapan ikan pari yang dianalisis, terdapat 10 kapal yang melakukan penangkapan ikan pari dalam jumlah banyak. Kapal penangkap pari yang menangkap terbanyak adalah KM. Mina Sempurna 89 (45.500 kg) (Gambar 3)



Diagram 2. Kategori 10 besar Kapal Penangkap Ikan Pari 
Tabel 2. Kapal Penangkap Ikan Pari dengan Klasifikasi Alat Tangkap

\begin{tabular}{|c|l|l|l|}
\hline No & Nama Kapal & Hasil Tangkapan Pari & Alat Tangkap \\
\hline 1 & MINA SEMPURNA 89 & 45500 & PURSE SEINE \\
\hline 2 & HASIL MAJU - 2 & 36800 & LONG LINE \\
\hline 3 & SRI CAHYO MURWANI & 27900 & GILL NET \\
\hline 4 & SRI RAHAYU & 27870 & LONG LINE \\
\hline 5 & PULAU IKAN & 23000 & GILL NET \\
\hline 6 & MUDAH JAYA - 13 & 21303 & LONG LINE \\
\hline 7 & GUNAWAN 28 JAYA - II & 21000 & LONG LINE \\
\hline 8 & GUNAWAN 28 JAYA - III & 20000 & LONG LINE \\
\hline 9 & HIDUP SENTOSA & 19500 & GILL NET \\
\hline 10 & USAHA JAYA 28 & 19475 & LONG LINE \\
\hline
\end{tabular}

Berdasarkan data tabel tersebut, bahwa pari dapat ditangkap oleh beberapa jenis alat tangkap. Kapal Mina Sempurna 99 dengan alat tangkap Purse Seine melakukan penangkapan ikan pari. Data tersebut mengidentifikasi kapal perikanan yang mendapatkan ikan pari yang banyak namun tidak selektif apakah penangkapan ikan pari sebagai tujuan utama pada saat keberangkatan kapal atau pennagkapan ikan pari sebagai baycatch. Stategi pengawasan terhadap kapal penangkapn ikan pari adalah pengetatan pemeriksaan kedatangan kapal perikanan oleh Pengawas Perikanan, upaya digitalisasi penandaan melalui stiker barcode terhadap kapal perikanan yang menangkap ikan pari,

\subsection{Peran Kelompok Masyarakat Nelayan}

Pelibatan kelompok masyarakat nelayan dalam melakukan pengawasan perikanan dan kelautan adalah amanat dalam UU perikanan No. 31 tahun 2004 jo UU No. 45 tahun 2009 pasal 66 dan UU No. 27 tahun 2007 jo UU No. 1 tahun 2014 pasal 36 didukung dengan amanat UU Nomor 31 Tahun 2004 tentang Perikanan, pada Pasal 67 yang menyatakan "Masyarakat dapat dilibatkan dalam membantu pengawasan perikanan"

Masyarakat atau anggota Pokmaswas dapat melaporkan informasi adanya dugaan pelanggaran dalam pengelolaan sumber daya kelautan dan perikanan kepada Pengawas Perikanan atau aparat penegak hukum terdekat. Masyarakat pengawas juga dapat melaporkan adanya dugaan adanya penangkapan ikan pari yang dilindungi penuh (ikan pari). Peran dan kiprah Pokmaswas tidak dapat dipandang sebelah mata sebab telah banyak berkontribusi meningkatkan pengawasan sumber daya kelautan dan perikanan oleh karenanya perlu ditingkat keterlibatannya. 


\section{KESIMPULAN DAN SARAN}

\subsection{Kesimpulan}

Ikan pari yang didaratkan sampai dengan bulan Desember sebanyak $1.261 .918 \mathrm{~kg}$. (1.261 ton), dengan pendaratan ikan pari terbanyak terjadi di bulan Agustus (467.939 kg) dengan Kapal penangkap pari yang menangkap terbanyak adalah KM. Mina Sempurna 89 (45500 kg). Adapun stategi pengawasan yang diterapkan diantaranya penerbitan aturan atau regulasi yang tepat berkaitan pengeluaran ikan pari dari pelabuhan pangkalan pendaratan ikan atau regulasi tentang distribusi peredaran ikan pari di masyarakat, digitalisasi penandaan melalui stiker barcode terhadap kapal perikanan yang menangkap ikan pari, serta penguatan laporan POKMASWAS (Kelompok Masyarakat Pengawas) atau pelibatan masyarakat dalam upaya melaporkan jika terdapat kapal penangkap ikan yang menangkap ikan pari secara berlebihan (over exploited)

\subsection{Saran}

Diperlukan beberapa penelitian lanjutan mengenai kapal yang khusus melakukan penangkapan ikan pari sebagai hasil tangkapan utama dan bukan sebagai hasil tangkapan sampingan (baycatch).

\section{UCAPAN TERIMAKASIH}

Kepala Stasiun PSDKP Cilacap serta Pejabat Eselon V Lingkup Stasiun PSDKP Cilacap

\section{DAFTAR PUSTAKA}

Camhi, M. S. J., Fowler, Musick A., Brautigam., Fordham. S. 1998. Sharks and Their Relatives, Ecology and Conservation. Occasional Paper of IUCN Species Survival Commision No. 20. IUCN. Cambridge.

Departemen Kelautan dan Perikanan. 2004. Undang-undang No. 31 Tahun 2004. Tentang Perikanan. Jakarta

Dharmadi., Fahmi. 2003. Fisheries Characteristic of Artisanal Sharks and Rays In Indonesia Waters. Jakarta.

Keputusan Menteri Kelautan dan Perikanan Nomor 4/KEPMEN-KP/2014 tentang Penetapan Status Perlindungan Penuh Ikan Pari Manta.

Peraturan Menteri Kelautan dan Perikanan Nomor 33/PERMEN-KP/2016 Tentang Organisasi

Dan Tata Kerja Unit Pelaksana Teknis Pengawasan Sumber Daya Kelautan Dan Perikanan.

Peraturan Menteri Kelautan dan Perikanan Nomor :17/PERMEN-KP/2014 Tentang Pelaksanaan Tugas Pengawas Perikanan 
[IUCN] International Union for Conservation of Nature .2015. IUCN Red List of Threatened Species. http://www.iucnredlist.org/. Diakses 10 November 2015 .

Kar, A., Raut S.K., Bhattacharya, S., Patra S., Basanta. 2017. Marine fishes of West Bengal coast, India: Diversity and conservation preclusion. Regional Studies in Marine Science. 16.

[SEAFDEC] South East Asian Fisheries Development Center. 2015. Fishery Statistical Bulletin of Southeast Asia 2013. [UPPP]

White W. T, Last P. R., Stevens J. D., Yearsley G. K., Fahmi., Dharmadi. 2006. Economically Important Sharks and Rays of Indonesia. ACIAR. Canberra. 